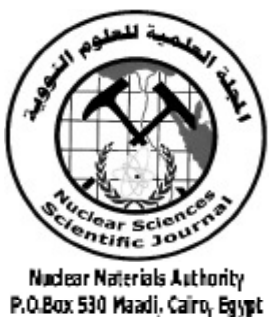

ISSN 2314-5609

Nuclear Sciences Scientific Journal

$5,33-47$

2016

http://www.ssnma.com

\title{
GENETIC AFFILIATION OF GOLD AND URANIUM MINERALIZATION IN EL-MISSIKAT GRANITE, CENTRAL EASTERN DESERT, EGYPT
}

\author{
FATHY A. AMMAR; SAYED A. M. OMAR and EL SAYED H. EL SAWEY \\ Nuclear Materials Authority, Cairo, Egypt
}

\begin{abstract}
Gabal El-Missikat granitic pluton is affected by two fault systems trending NW-SE (the oldest) and ENE-WSW directions. It is one of the uranium occurrences in the Eastern Desert of Egypt. The northwestern margins of El-Missikat pluton, along its contact with the gneissose quartz diorite, are dissected by numerous reactivated fractured shear zones running generally ENE-WSW to NE-SW and dipping about $60^{\circ}-70^{\circ}$ to SE. Many white (oldest), smoky or black and jasperoid (youngest) silica veinlets fill the fractures of these shear zones.

These veins are of irregular shape and variable thickness ranging from few centimeters to about three meters. They are chiefly affected by silicification, sericitization, hematitization, kaolinization and hydrothermal alterations processes. The smoky black veins are hosting secondary uranium and fluorite-, sulphide-gold mineralizations.

Polished surface studies, ICP-ES and Atomic Absorption as well as Scanning Electron Microscope measurements recorded galena, pyrite chalcopyrite, sphaleriteand molybdenite in the black and jasperoid mineralized veins. Gold associated with ore mineral assemblage as pyrite, chalcopyrite, sphalerite, galena, sheelite and iron oxides. The identified sulphide minerals not bearing gold are recorded. Gold are relatively coarse-grained, massive and metallic yellow or stretched bronze colored particles.

The recorded secondary $U$ minerals associates the sulphide gold-mineralization in the black and jasperoid silica veins.

Regarding the mobility of both uranium and gold, $\mathrm{U}^{4+}$ mobilized in oxidizing medium and migrate and transport as $\mathrm{U}^{6+}$, then deposited later as $\mathrm{U}^{4+}$ when the medium changes to be reducing characterized by high $\mathrm{fO}_{2}$. On contrary, gold mobilized when the medium is complex $\mathrm{AuCl}^{3-}$ ion bearing. Consequently, ElMissikat granitic pluton affected by oxidizing $\mathrm{Au}$ and $\mathrm{Cl}^{3-}$ bearing high temperature hydrothermal solutions that leached $\mathrm{U}^{4+}, \mathrm{W}$ and Mo from the granitic mass as $\mathrm{U}^{6+}$, later decrease of temperature, both $\mathrm{U}$ and gold deposited as well as the sulphide minerals of $\mathrm{Pb}, \mathrm{Zn}, \mathrm{cu}, \mathrm{Fe}$ and $\mathrm{Mo}$ in the high temperature hydrothermal fluids were deposited with increase of $\mathrm{S}^{+2}$ ion.
\end{abstract}

\section{INTRODUCTION}

Gabal El-Missikat granitic pluton lies at the extreme northwestern corner of the central Eastern tectonic Domain, directly south to Qena-Safaga paved road at $\mathrm{km} 85$ from Qena. This pluton is bounded by lat. $26^{\circ} 15^{\prime}$ to $26^{\circ} 30^{\prime} \mathrm{N}$ and long. $33^{\circ} 15^{\prime}$ to $33^{\circ} 30^{\prime} \mathrm{E}$ as a high mountainous peak $(891 \mathrm{~m}$. a.s.l) of younger granite. It covers about $377.4 \mathrm{~km}^{2}$ as an area with an oval outline elongated roughly in a NW direction.

El-Missikat granitic pluton representing one of the important uranium occurrences in the Eastern Desert of Egypt have been studied by several workers (El-Kassas, 1974; Bakhit, 1978; El-Shazly et. al., 1981; Habib, 
1982; Attawyia, 1984; El-Tahir, 1985; Bakhit et. al., 1985; Abu Deif, 1985 and 1992; Hussein et. al., 1986; Mohamed, 1988 and 1995; Ahmed, 1991; Abu-Deif et. al., 1997; Orabi, 1999; Ibrahim, 2002; Amer et. al., 2005, Ammar, 2007 and El-Sherif, 2013). These studies concentrated on the uranium mineralization existing in the shear zone. On studying the sulphide mineral constituents associating the uranium mineralizations, Ammar, (2007) recorded gold mineralization. In this respect, gold mineralization associating $U$ mineralizatiom is also recorded in the younger granite pluton of El Aradiya and northward in the Gattar granite (Hassaan, 2011). The present work aims at probable genetic affiliation of the gold mineralization in association with the U-mineralization of El-Missikat granitic pluton to interpret this feature.

\section{SAMPLING AND METHODS OF ANALYSES}

Ten samples were collected from the mineralized zones related to the silica veins cutting El-Missikat granite. These samples represent white silica (three samples), black silica (three samples), jasperoid silica (two samples) and host granite (two samples). The white silica samples collected from a site nearby the black silica are coated by hematite and limonite. The collected black silica samples filling the fractures of the shear zone, being hematitized, containing vugs that coated by enriched secondary uranium minerals. The jasperoid silica samples were collected from the highly brecciated veins that contain fragments of proper granite and deformed fragments of silica. The granite samples were collected from a site nearby the alteration zones. This granite is highly altered, kaolinitized and/or sericitized.

Each of the studied rock samples as well as prepared composite sample, from the three silica varietes, were crushed, ground, quartered, splitted and sieved with $(-30+60),(-60$ $+230)$ and $(-230)$ mesh sizes. Heavy liquid separation using bromoform (sp.gr $=2.85$ ) was carried out to separate the heavy minerals constituents from the $(-60+230)$ mesh size fractions, followed by removing magnetite from the heavy fraction by hand magnet. The heavy minerals were picked under the binocular microscope for Scanning Electron Microscope (SEM) investigations.

Polarized and ore microscopes were used to investigate the thin sections and polished surfaces, respectively. EDX investigations and probe analysis of some separated grains were carried out using equipment Model JEOL \{with System Resolution $=93 \mathrm{eV}$, Quantitative method (ZAF, 2 interations) at $20 \mathrm{~K} \mathrm{eV}\}$.

The X-ray fluorescence technique (XRF) was used to determine the trace element, content using PHILIPS X-Unique-II Spectrometer with automatic sample changer PW 1510, (30 positions). The detection limit for the elements measured by XRF technique is estimated at 2 ppm for $\mathrm{Rb}, \mathrm{Nb}, \mathrm{Ga}, \mathrm{Co}, \mathrm{Y}$ and $\mathrm{Sr}$ and at $8 \mathrm{ppm}$ for $\mathrm{Pb}$ and $\mathrm{Cu}$ and $5 \mathrm{ppm}$ for other measured trace elements. ICP-AES (Plasmaquant, MO Analytic, Jeva) for major elements analyses and ICP-MS (PQ EXAZ, Thermo-Elemental) Technique for rare earth elements (REE) measurements were used.

Gamma-ray, X-ray fluorescence (XRF) and Scaning Electron Microscope (SEM) as well as the other applied techniques were carried out in the laboratories of the Egyptian Nuclear Materials Authority (NMA). The ICP analyses and probe analysis were undertaken in the Geology, Mineralogy and Geochemistry Institute, Martin-Luther University, Halle, Germany.

\section{GEOLOGIC SETTING}

The country rock types are granitic gneiss, ophiolitic serpentinite, amphibolites, island metagabbro, metadiabase, metabasalt, metaandesite, cordelarian calc-alkaline granite types, felsite and alkaline granite. These rock types at El-Missikat younger granite pluton 
crop out as concentric oval body extending NW-SE. This granite body is affected by several NW-SE (the oldest) and ENE-WSW (the youngest) trending faults expressed by wadis. It forms the highest peak in the area (Fig. 1). The Northwestern margins of El-Missikat granite, along its contact with the gneissose quartz diorite (Fig. 2) are dissected by numerous reactivated fractured shear zones running generally ENE-WSW to NE-SW and dipping about $60^{\circ}-70^{\circ}$ to $\mathrm{SE}$ (Fig. 3).

The ENE trend is apparently represent- ing reactivated tensional fractures genetically related to the NW left-lateral strike slip fault (Habib, 1982). This shear zone contains different silica veins concentrically arranged. The white siliceous veins are arranged directly along the walls of the shear zone grade inward into the black type and end by the jasperized ones in the core. The most significant mineralization bearing are the smoky to black and red jasperized zones of the veins (Fig. 4). These veins are of irregular shape with variable thickness ranging from few centimeters

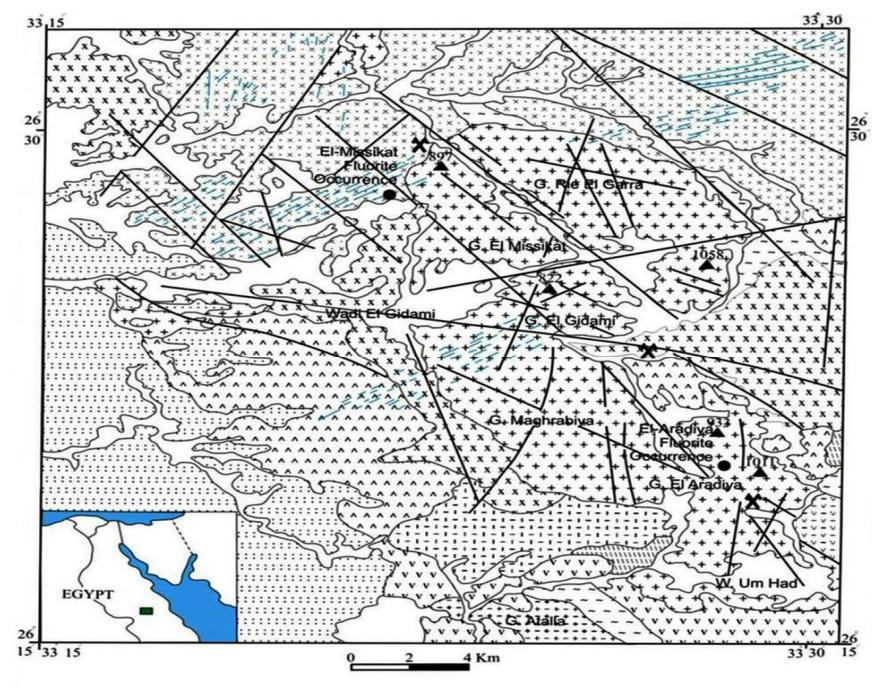

Fig. 1: Geologic Map of El-Missikat Area (After Abu Dief, 1985)

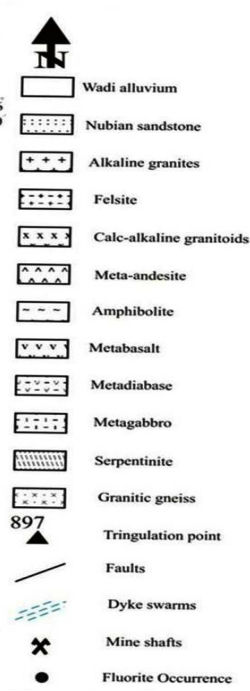

- Fluorite Occurrence

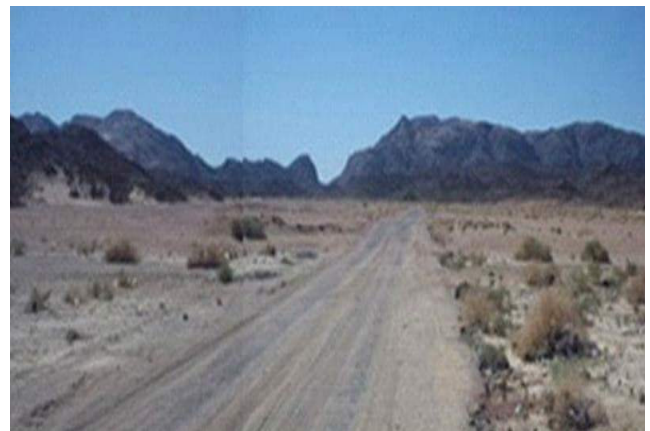

Fig. 2: Photograph Showing panoramic view of Gabal El-Missikat granite

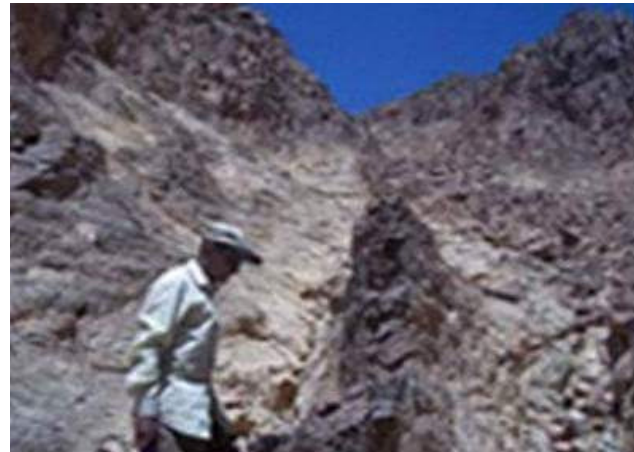

Fig. 3 : Photograph Showing general view of ElMissikat granitic shear zone 


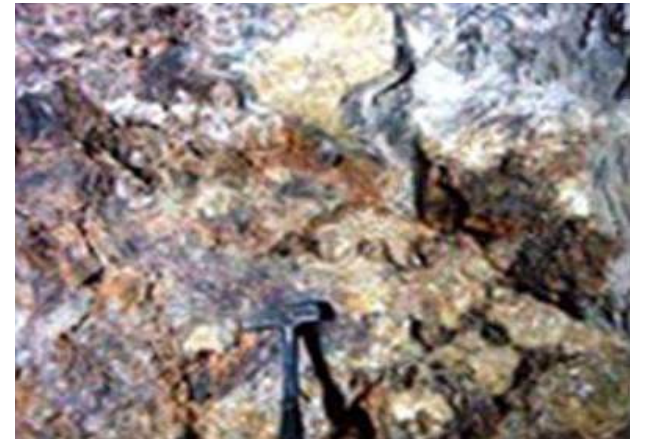

Fig. 4: Photograph showing brecciated and hematitized black and red silica fragments

to about three meters. The black silica veins host secondary uranium minerals, fluorite, galena, pyrite, chalcopyrite and molybdenite.

The light colored veins display white, light-grey, pale-brown colors. Under microscope, they consist mainly of anhedral quartz grains $0.2-1.5 \mathrm{~mm}$ in length and as coarse aggregates of quartz which show interlocking grain boundaries with undulose extinction.

\section{Alteration Features}

The field studies indicated that G.El-Missikat area had suffered hydrothermal alteration processes viz., silicification, sericitization, kaolinitization and ferrugination in the form of hematitization associated with denderitic manganese oxides, chiefly concentrated along faults, joints and fracture zones. These alteration processes led to bleaching and various degrees of red colorization of the shear zone (silica vein). Silicification is the most important alteration process in the chief shear zone. The process manifested by more than one generation of silica veins, white silica, black silica and red jasper. The light colored siliceous veins represent the earliest generation followed by the black and finally by the red jasperized ones which seems followed immediatly the black silica. Each generation is brecciated and cemented by the younger type. Intensive kaolinitization, sericitization and hematitization affect the gran- ite along the contacts with the silica vein in some sites (Figs. 5\&6). The last silicification process is expressed (Fig. 7) as small zone of red and black quartz fragments cemented by silica forming breccia occupying the sides of the shear plane ranging from 30 to $40 \mathrm{~cm}$ in width and is the richest in uranium, fluorite and sulfide mineral constituents.

Through the process of silicification; secondary quartz is liberated as fine crystals or amorphous silica and as chalcedony filling fractures and cavities (Fig. 8). This stage of alteration is characterized by reduction of magnetite to euhedral crystals (Fig. 6).

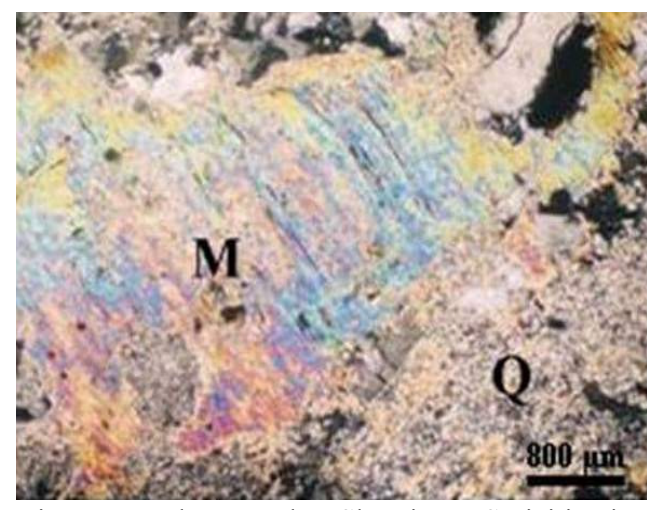

Fig. 5: Photograph Showing Sericitization associated with secondary muscovite (M) and finegrained to cryptocrystalline quartz (Q).

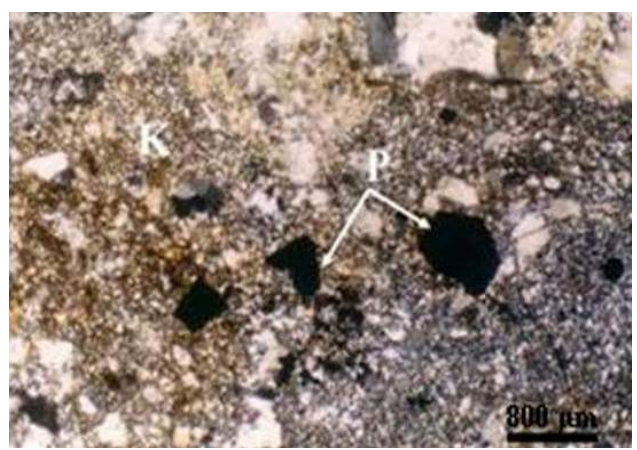

Fig. 6: Photograph showing kaolinization $(\mathrm{K})$ of plagioclase surrounded with secondary quartz. Some cubes of opaque (pyrite P ??) are distributed inside the kaolinized groundmass 


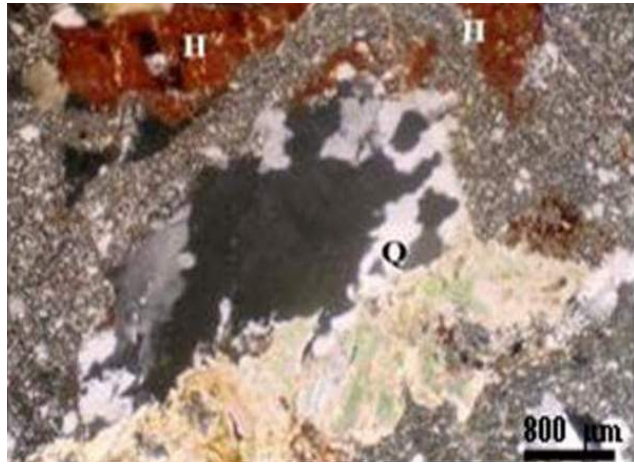

Fig. 7: Photograph showing silicification (Q) and hematitization $(\mathrm{H})$ associating primary quartz

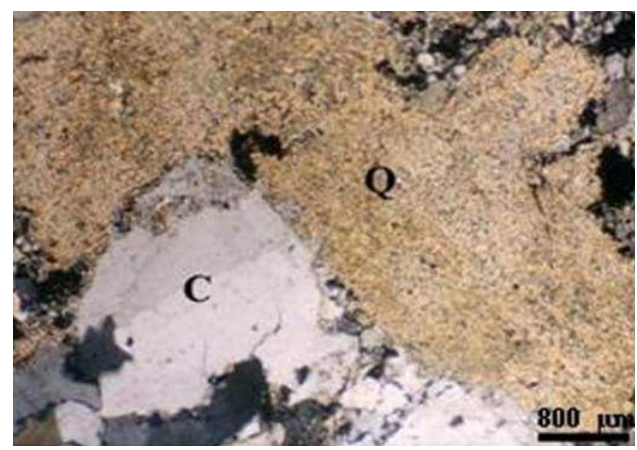

Fig. 8: Photograph showing chalcedony (C) embedded in cryptocrystalline quartz groundmass (Q)

\section{URANIUM MINERALIZATION}

The field radiometric measurements were carried out using GR-110 to estimate eU, eTh and $\mathrm{K} \%$. The obtained field radiometric measurements show that the white silica veins possess radioactivity ranging from 250 c.p.s up to 300 c.p.s, the black silica samples more than 3000 c.p.s. and jasperoid silica samples 1500 c.p.s. Table (1) shows the eU, eTh, Ra (ppm) and ${ }^{40} \mathrm{~K}(\%)$ contents as well as the chemically measured uranium $\left(U_{\text {ch. }}\right.$ in $\left.p p m\right)$ of the studied rock samples manifested that the black silica veins have the highest ( $\mathrm{eU}$ and/or $\mathrm{U}_{\text {ch }}$ ), eTh and Ra contents, while the white silica veins and the altered granitic samples show the least (eU and/or $\mathrm{U}_{\mathrm{ch}}$ ), eTh and $\mathrm{Ra}$ contents through the jasperoid the silica veins.

The strongly brecciated jasperized silica veins show obvious variation in $U$ content (16-465 eU; 4-217 Uch). The gold content is recorded in the analyzed samples. However, the jasperoid silica vein contains the highest Au content (116 and 118ppm). Meanwhile, the $\mathrm{U}_{\text {ch }}$ and $\mathrm{Au}$ contents are reversible to each other in the black silica samples. The Au content is the least in the sample containing the

Table 1: Gamma-ray spectrometric measurements, chemical uranium content and gold (ppm) of El-Missikat shear zone samples

\begin{tabular}{|c|c|c|c|c|c|c|c|c|}
\hline $\begin{array}{l}\text { Rock } \\
\text { type }\end{array}$ & S.No. & $\begin{array}{r}\text { eU } \\
(\mathbf{p p m})\end{array}$ & $\begin{array}{r}\text { eTh } \\
\text { (ppm) }\end{array}$ & " K\% & $\begin{array}{r}\text { Ra } \\
(\mathbf{p p m})\end{array}$ & $\mathbf{e T h} / \mathbf{e U}$ & $\begin{array}{r}U \\
\text { (chemically) } \\
(\text { ppm) }\end{array}$ & $\begin{array}{r}\text { Gold } \\
\text { (ppm) }\end{array}$ \\
\hline \multirow{3}{*}{$\begin{array}{l}\text { White } \\
\text { silica }\end{array}$} & 1 & 16 & 19 & 4 & 12 & 1.19 & 8 & 64 \\
\hline & 2 & 13 & 17 & 0.25 & 12 & 1.31 & 5 & 58 \\
\hline & 8 & 27 & 36 & -- & 18 & 1.33 & 11 & 154 \\
\hline \multirow{3}{*}{$\begin{array}{l}\text { Black } \\
\text { silica }\end{array}$} & 3 & 1983 & 474 & -- & 2007 & 0.24 & 965 & 89 \\
\hline & 5 & 571 & 49 & -- & 449 & 0.09 & 248 & 155 \\
\hline & 7 & 654 & 47 & -- & 599 & 0.07 & 261 & 200 \\
\hline \multirow{2}{*}{$\begin{array}{l}\text { Jasperoid } \\
\text { Silica }\end{array}$} & 4 & 465 & 37 & -- & 435 & 0.08 & 217 & 118 \\
\hline & 6 & 16 & 28 & -- & 12 & 1.75 & 4 & 116 \\
\hline \multirow{2}{*}{$\begin{array}{l}\text { Altered } \\
\text { granites }\end{array}$} & 9 & 15 & 32 & 2.34 & 13 & 2.13 & 7 & 81 \\
\hline & 10 & 16 & 27 & 3.98 & 12 & 1.69 & 6 & 74 \\
\hline
\end{tabular}


highest content of eU and $\mathrm{U}_{\mathrm{ch}}$ and vice versa.

This U-mineralization was considered by El-Kassas, (1974) and Bakhit, (1978) to be of fracture-filling type of hydrothermal origin and related to the latest phase of alkali feldspar granites magma.

\section{Ore Minerals Assemblages}

The recorded assemblage of ore minerals are gold, uranium, pyrite, pyhrrolite, sphalerite, galena, magnetite, scheelite, fluorite, barite, goethite, and hematite being secondary ore minerals.

Binocular microscope investigations show that gold exhibits relatively coarse-grained, sometimes massive and/or stretched bronze colored particles (Fig. 9). Polished surfaces show that gold exhibits bright golden specs
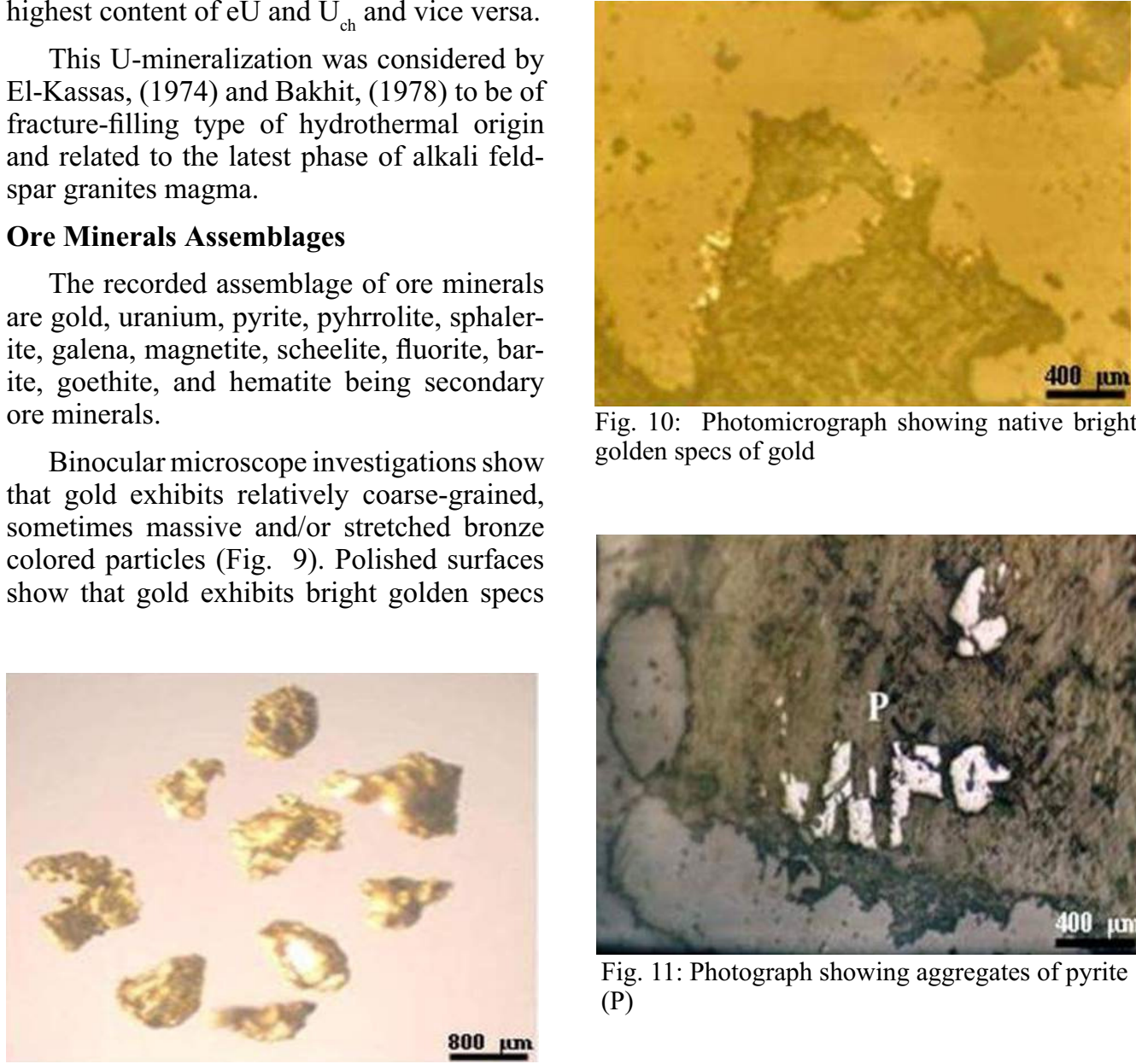

Fig. 10: Photomicrograph showing native bright golden specs of gold

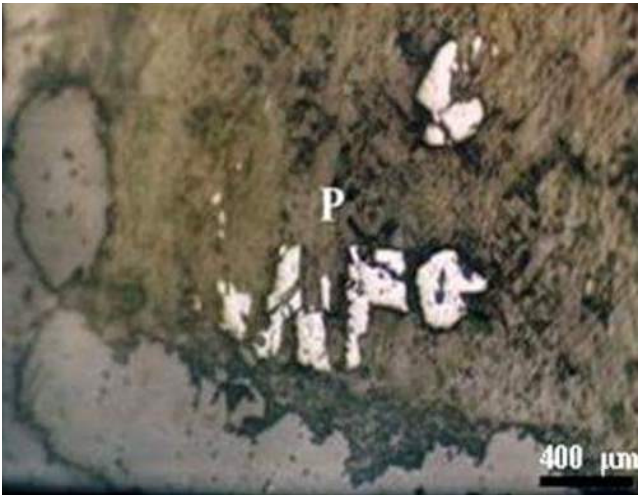

Fig. 11: Photograph showing aggregates of pyrite (P)

Fig. 9: Photomicrograph showing massive and bronze-colored gold particles

distributed individually in the samples, while the present sulphides were free from any gold content (Fig. 10).

\section{The Ore Mineral Constituents}

The polished surface studies show that pyrite of cubic form is the main sulphide mineral constituent (Fig. 11) and the pyritohedral form (Fig. 12). Occasionally, some of the pyrites are altered to pyhrrotite (Fig. 13). Deformed galena is distributed in the sample surfaces (Fig. 14). Sphalerite cubes and mag-

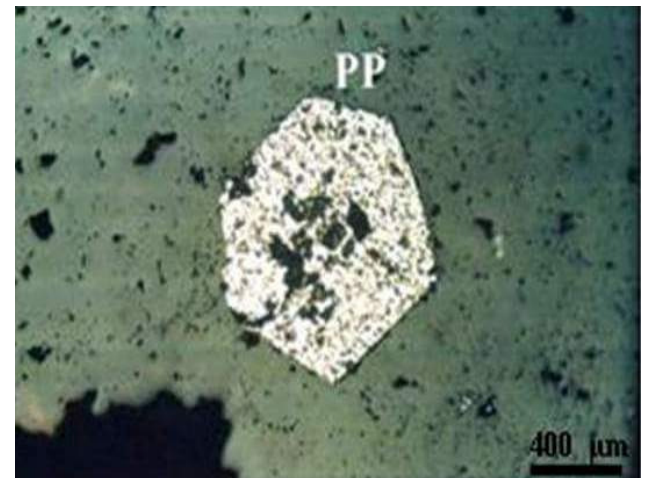

Fig. 12: Photograph showing pyritohedral pyrite crystal (PP) 


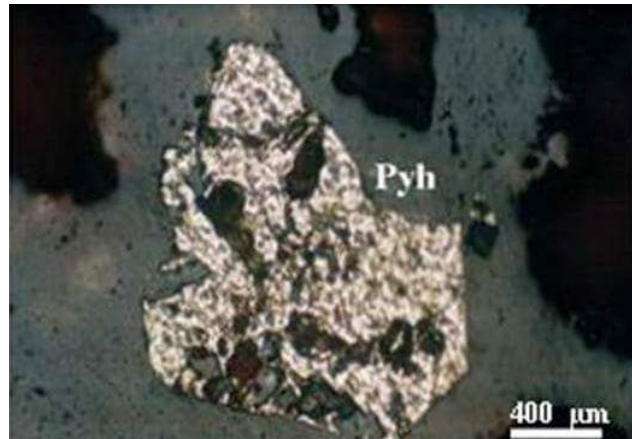

Fig. 13: Photograph showing pyhrrotite (Pyh) after pyrite

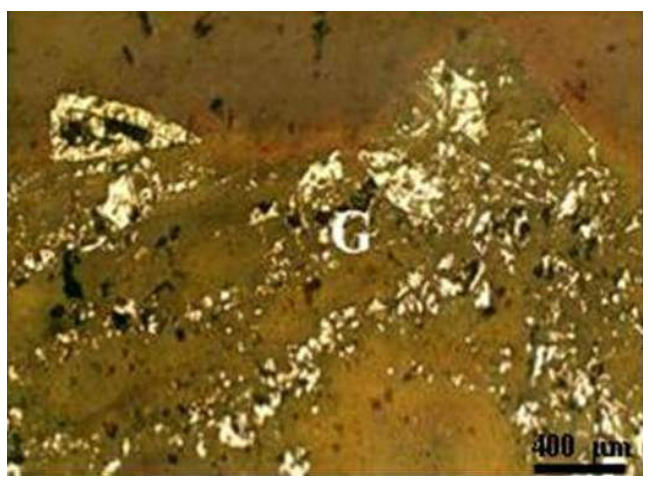

Fig. 14: Photograph showing galena aggregates (G)

netite crystals (Figs. 15\&16) were identified. Native gold specs are distributed in-between the main components (see Figs. 11\&12). It is clear that the recorded sulphide minerals are free from any gold specs.

Figures 17-24 show grains of the ore mineral assemblages and the constituents associating gold mineralization investigated by the Scanning Electron Microscope (Figs. 25-30) and analyzed with the probe (Tables 2 and 3 ) in order to explain their chemical features and to clarify presence of any gold specs.

The other ore mineral constituents include magnetite, hematite and goethite, scheelite, fluorite and barite.

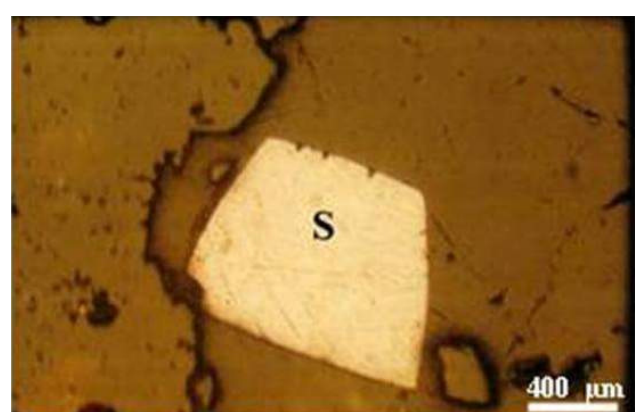

Fig. 15: Photograph showing cube sphalerite (S) crystal

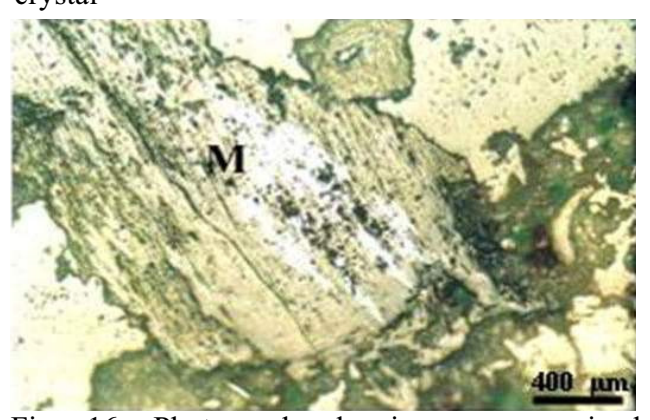

Fig. 16: Photograph showing coarse-grained magnetite (M)

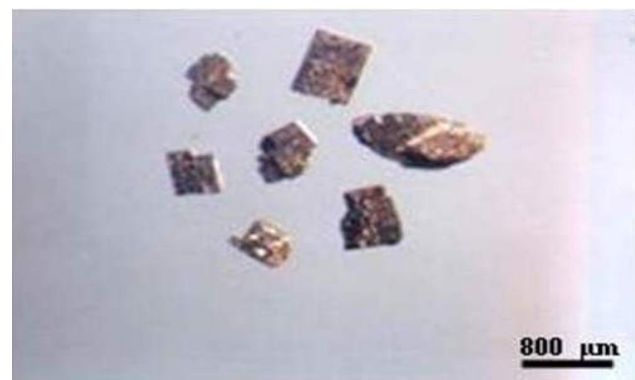

Fig. 17: Photograph showing galena particles, some are altered and enclosed quartz impurities,

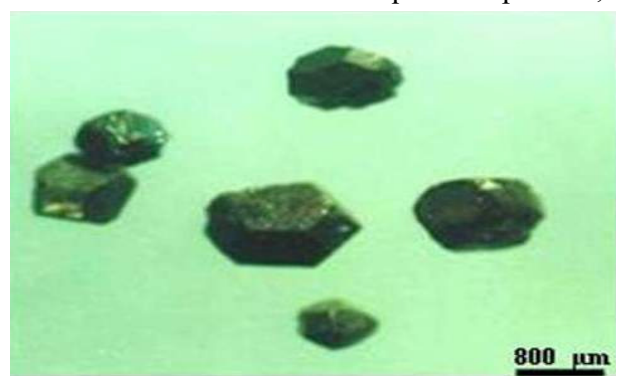

Fig. 18: Photograph showing Pyritohedral, dark brown pyrite particles 


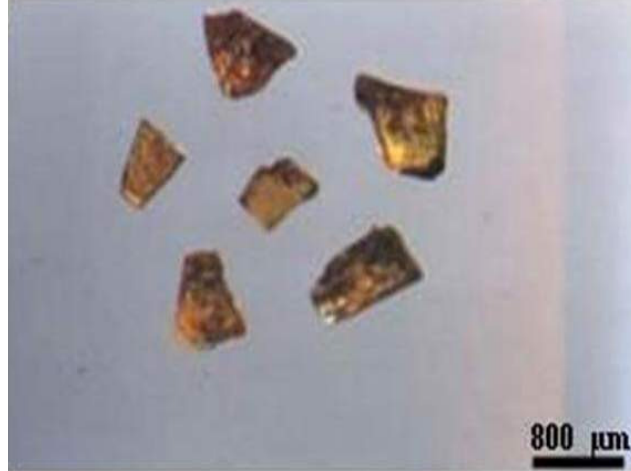

Fig. 19: Photograph showing cubic and prismatic yellowish brown sphalerite particles

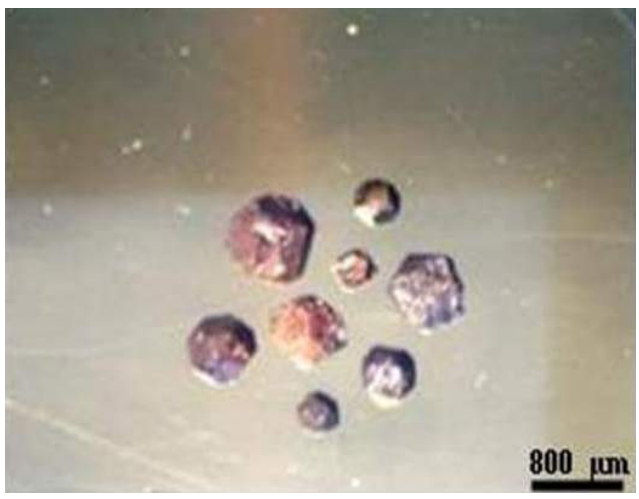

Fig. 20: Photograph showing dark brown, fine- to medium-grained iron oxides particles

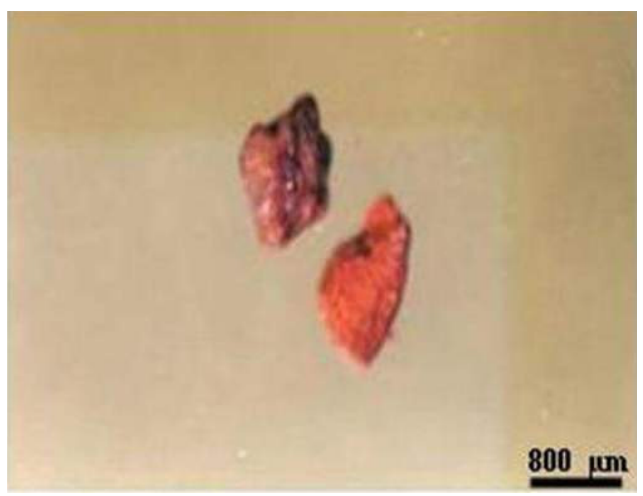

Fig. 21: Photograph showing reddish brown hematite particles

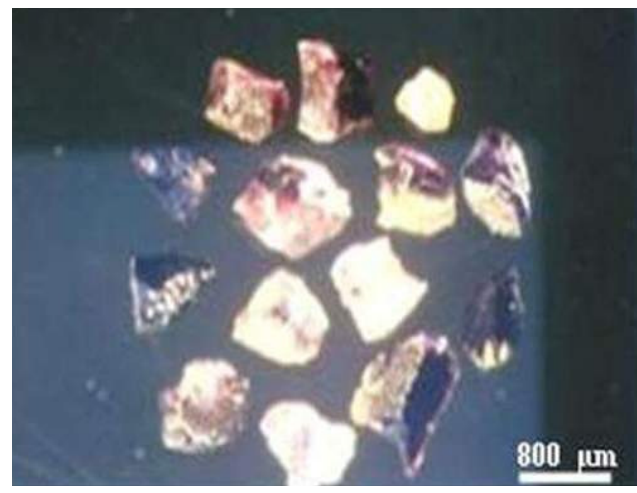

Fig. 22: Photograph showing white, pale violet and violet fluorite particles

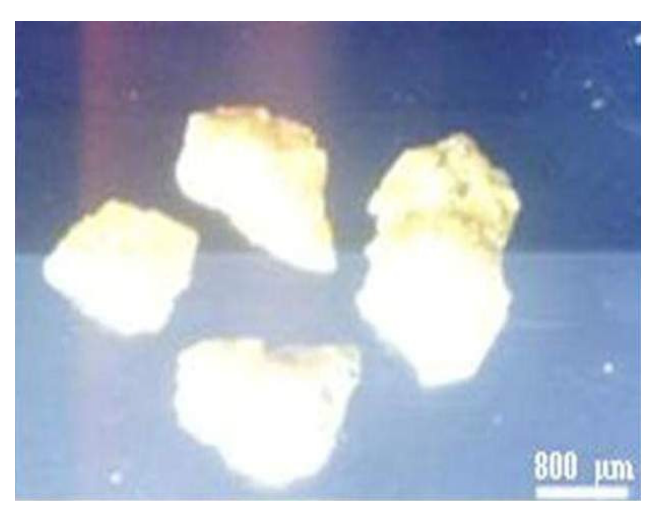

Fig. 23: Photograph showing coarse-grained barite particles, some are stained with iron oxides

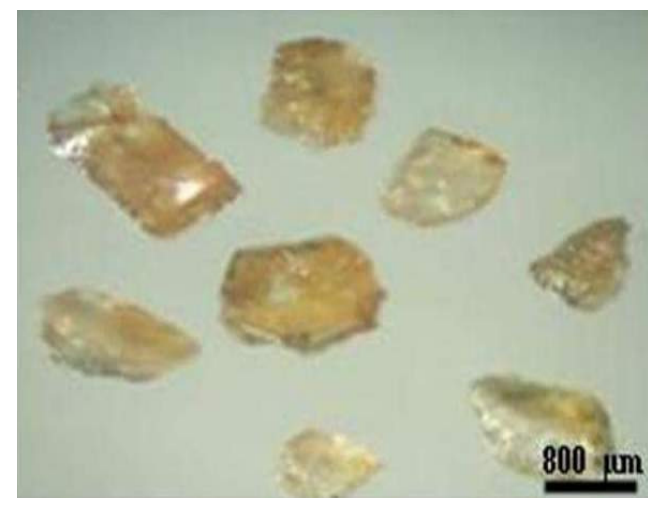

Fig. 24: Photograph showing yellowish and coarse-grained scheelite grains 


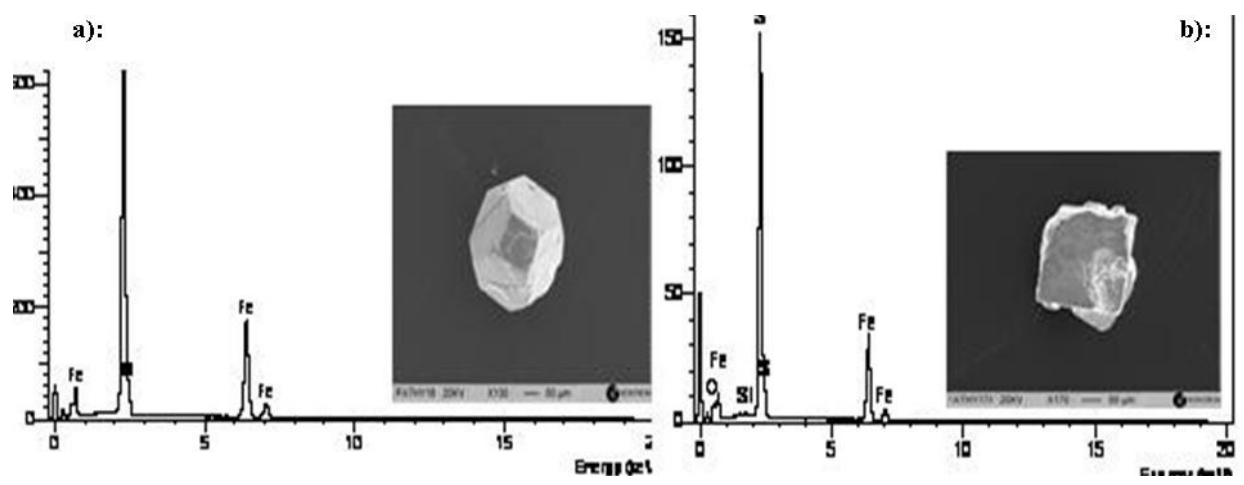

Fig. 25: EDX analysis and back scattered image of (a): pyritohedral (b) :cubic pyrite particle

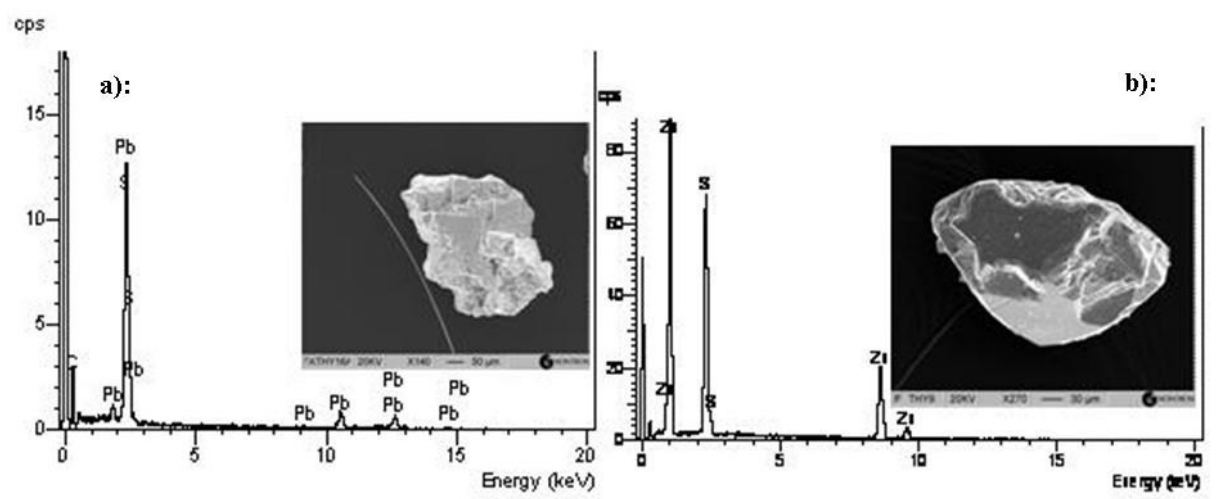

Fig. 26: EDX analysis and back scattered image of grains (a): galena (b): sphalerite
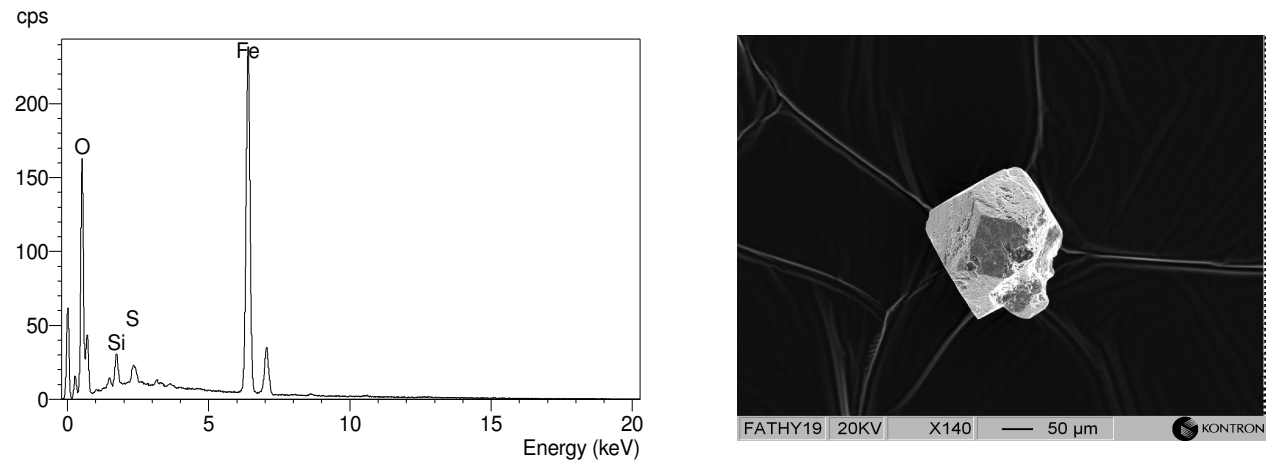

Fig. 27: EDX analysis and back scattered image of goethite after cubic pyrite particle 

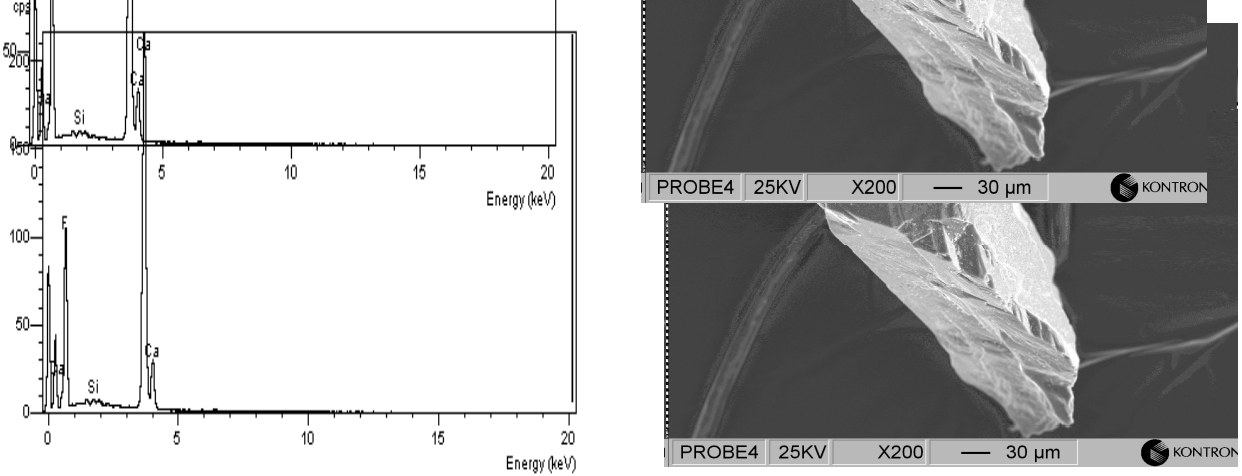

Fig. 28: EDX analysis and back scattered image of fluorite particle
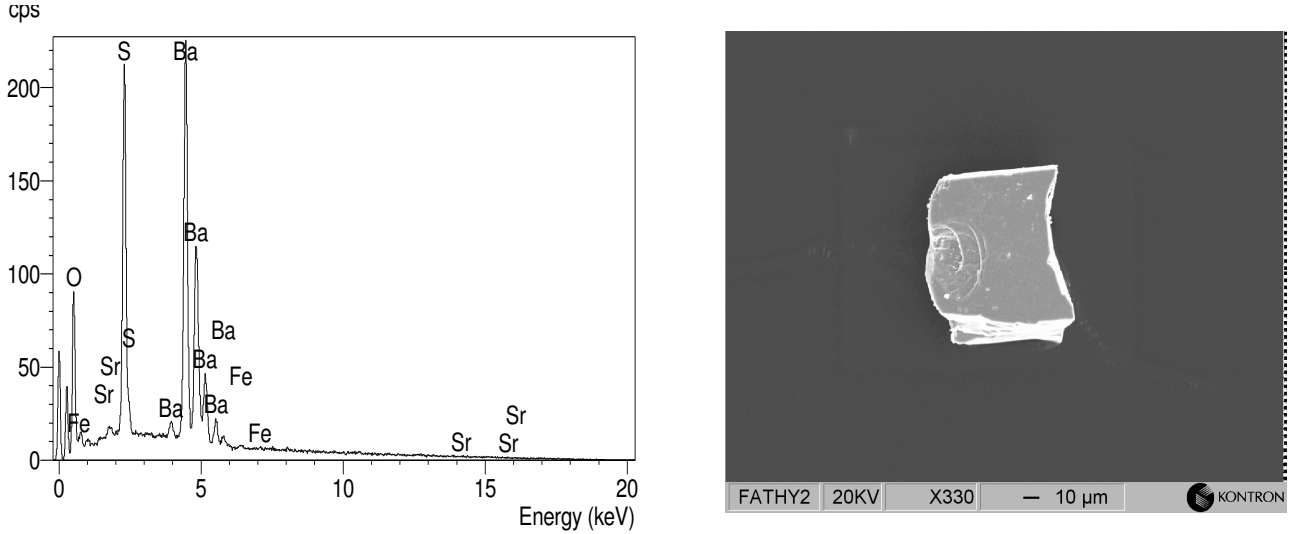

Fig. 29: EDX analysis and back scattered image of barite grain

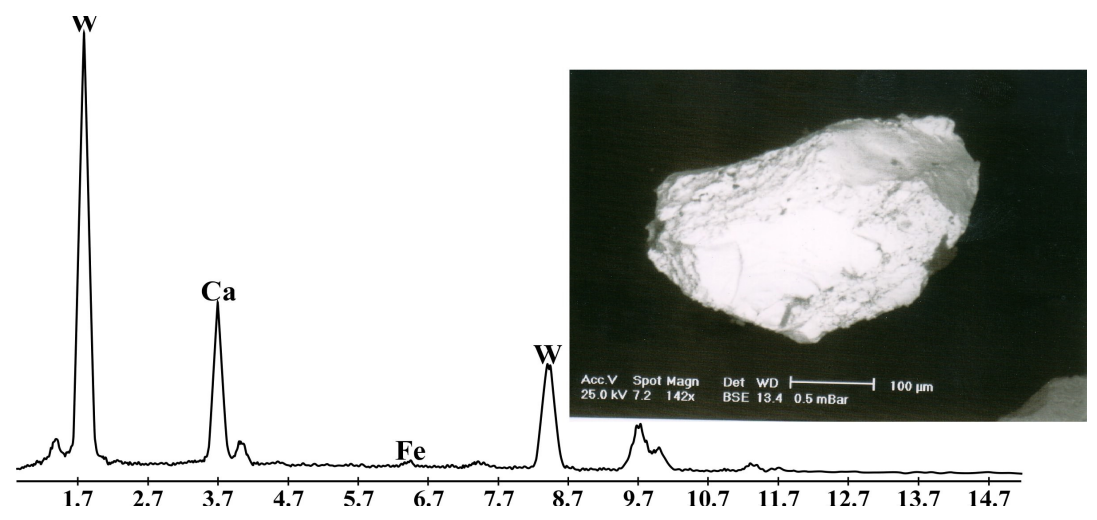

Fig. 30: EDX analysis and back scattered image of scheelite grain 
Table 2: Probe analyses of sulphide ore minerals in $\mathrm{wt} \%$

\begin{tabular}{|c|c|c|c|c|c|}
\hline \multirow{2}{*}{ 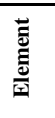 } & \multirow{2}{*}{ 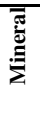 } & \multicolumn{3}{|c|}{ Pyrite } & \multirow[b]{2}{*}{ Sphalerite } \\
\hline & & $\begin{array}{r}\text { Pyritohedral } \\
\text { Pyrite }\end{array}$ & $\begin{array}{l}\text { Cubic } \\
\text { Pyrite }\end{array}$ & Galena & \\
\hline $\bar{O}$ & & 2.98 & 2.16 & 13.52 & ... \\
\hline $\mathbf{S i}$ & & 0.22 & 0.17 & 0.62 & $\ldots$ \\
\hline $\mathbf{S}$ & & 50.71 & 52.07 & 18.23 & 33.48 \\
\hline $\mathbf{P b}$ & & $\ldots$ & $\ldots$ & 67.63 & ... \\
\hline $\mathbf{F e}$ & & 45.93 & 45.60 & & \\
\hline Zn & & $\ldots$ & $\ldots$ & $\ldots$ & 66.52 \\
\hline Al & & 0.16 & $\ldots$ & $\ldots$ & \\
\hline Ba & & $\ldots$ & $\ldots$ & $\ldots$ & $\ldots$ \\
\hline Total & & 100 & 100 & 100 & 100 \\
\hline
\end{tabular}

Table 3: Probe analyses of the other ore assemblage minerals in $\mathrm{wt} \%$

\begin{tabular}{|c|c|c|c|c|c|}
\hline 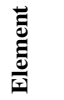 & 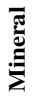 & $\begin{array}{r}\text { Iron } \\
\text { Oxide }\end{array}$ & Fluorite & Barite & Scheelite \\
\hline $\mathbf{F}$ & & $\ldots$ & 62.48 & $\ldots$ & $\ldots$ \\
\hline $\mathrm{Ca}$ & & $\ldots$ & 35.88 & $\ldots$ & 17.48 \\
\hline $\mathbf{S i}$ & & 2.29 & 0.39 & $0.16 \%$ & $\ldots$ \\
\hline $\mathbf{S}$ & & 0.63 & 0.12 & 14.14 & $\ldots$ \\
\hline $\mathrm{Fe}$ & & 61.86 & 0.15 & $\ldots$ & 00.90 \\
\hline $\mathbf{K}$ & & $\ldots$ & 0.14 & ... & $\ldots$ \\
\hline Th & & $\ldots$ & 0.25 & $\ldots$ & $\ldots$ \\
\hline $\mathbf{U}$ & & $\ldots$ & 0.59 & $\ldots$ & $\ldots$ \\
\hline $\mathbf{O}$ & & 35.22 & $\ldots$ & 20.46 & $\ldots$ \\
\hline Ba & & $\ldots$ & ... & 65.06 & $\ldots$ \\
\hline W & & ... & ... & $\ldots$ & 81.63 \\
\hline $\mathrm{Cr}$ & & $\ldots$ & $\ldots$ & $\ldots$ & $\ldots$ \\
\hline Total & & 100 & 100 & 100 & 100 \\
\hline
\end{tabular}

\section{GENESIS OF GOLD MINERALIZATION}

The ten analyzed samples representing the three silica vein types and the surrounding alteration zones were analyzed in order to measure the gold and silver contents using ICP and Atomic Absorption Techniques. The obtained data were listed in Table (4) which shows that the black and jasperoid silica have relatively high gold contents, whereas silver traces are recorded in the black and white veins. At the same time, the altered granitic samples have the lowest gold contents.
Table 4: Gold contents (ppm) in the different studied silica samples and altered granite.

\begin{tabular}{lrrr}
\hline Rock type & S.No. & Au & Ag \\
\hline White & 1 & 64 & 5 \\
silica & 2 & 58 & 4 \\
& 8 & 154 & 3 \\
& Av. & 92 & 4 \\
Black & 3 & 89 & 5 \\
silica & 5 & 155 & 4 \\
Jasperoid & $\mathbf{7}$ & 200 & 3 \\
Silica & $\mathbf{A v}$. & 148 & 4 \\
& $\mathbf{4}$ & 118 & \\
& 6 & 116 & \\
Altered & Av. & 117 & \\
granites & $\mathbf{9}$ & $\mathbf{8 1}$ & \\
& Av. & 77.5 & \\
\hline
\end{tabular}

SEM and EDAX semi quantitative analysis (Fig. 31) clarify the presence of native gold specs.

\section{Genetic Affiliation}

The interrelationship between the uranium mineralization and the recorded gold in only the black and jasperoid silica veins of ElMissikat shear zone can be explained through some changes of the oxidation/reduction geochemical parameters of the hydrothermal fluids affected El Missikat pluton.

\section{DISCUSSION AND CONCLUSIONS}

1- The northwestern margins of El-Missikat pluton, along its contact with the gneissose quartz diorite are dissected by numerous reactivated fractured shear zones running generally ENE-WSW to NE-SW and dipping about $60^{\circ}-70^{\circ}$ to SE. Many white (oldest), smoky or black and jasperoid (youngest) silica veinlets fill the fractures of these shear zones. 


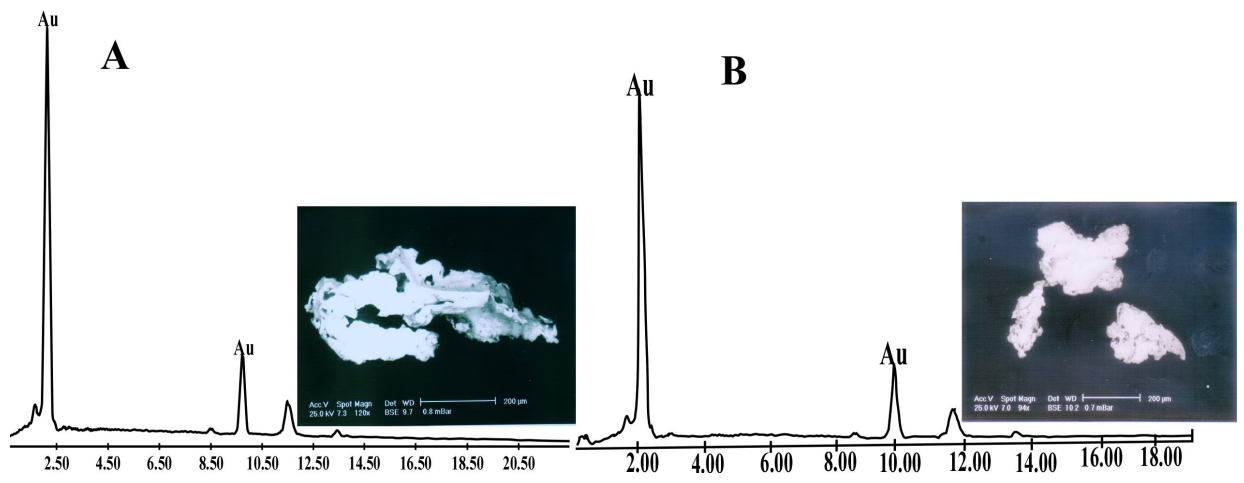

Fig. 31: SEM and EDX analysis and back scattered image of native gold particles

2- Galena, pyrite chalcopyrite, sphaleriteand molybdenite are present in the black and jasperoid mineralized veins. Gold is associated with ore mineral assemblage pyrite, chalcopyrite, sphalerite, galena, sheelite and iron oxides. The identified sulphide minerals not bearing gold are recorded. Gold are relatively coarse-grained, massive and metallic yellow or stretched bronze colored particles.

3- Regarding the mobility of both uranium and gold, $\mathrm{U}^{4+}$ mobilized in oxidizing medium and migrate and transport as $\mathrm{U}^{6+}$, then deposited later as $\mathrm{U}^{4+}$ when the medium changes to be reducing characterized by high $f \mathrm{O}_{2}$. On contrary, gold mobilized when the medium is complex $\mathrm{AuCl}^{3-}$ ion bearing. Consequently, El-Missikat granitic pluton affected by oxidizing $\mathrm{Au}$ and $\mathrm{Cl}^{3-}$ bearing high temperature hydrothermal solutions that leached $\mathrm{U}^{4+}, \mathrm{W}$ and Mo from the granitic mass as $\mathrm{U}^{6+}$, later decrease of temperature, both $\mathrm{U}$ and gold deposited as well as the sulphide minerals of $\mathrm{Pb}$, $\mathrm{Zn}, \mathrm{Cu}, \mathrm{Fe}$ and $\mathrm{Mo}$ in the high temperature hydrothermal fluids were deposited with increasing of $\mathrm{S}^{+2}$ ion.

Table (5) shows that the conditions required for $\mathrm{Au}$ transport are intermediate between those mentioned by Dubessy et al. (1987) for U and Sn-W. This may explain
Table 5: Conditions of mobilization and deposition of $\mathrm{Au}, \mathrm{U}$ and $\mathrm{Sn}-\mathrm{W}$

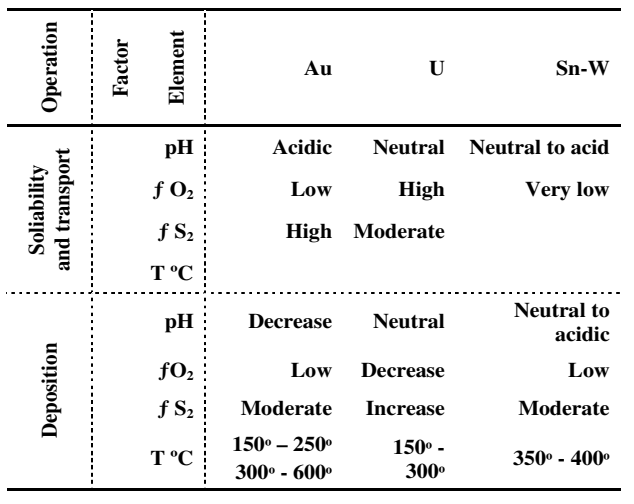

why discrete Au-mineralizations are associated in some cases with U (Vanhanen, 1987, for instance) but more frequently with Sn-W deposits.

These mineral associations are recorded in the studied silica veins as: uranium minerals, $\mathrm{Au}$ specs and scheelite. In fact, the presence of scheelite and the absence of cassiterite is a further evidence for the prevalence of reducing conditions during the deposition of $\mathrm{U}, \mathrm{Au}$ and Sn-W mineralizations since the crystallization of cassiterite necessitates oxidizing condition. 
It may be concluded that the hydrothermal fluids responsible for the formation of the studied silica veins and the deposition of $\mathrm{U}$ and $\mathrm{Au}$ mineralizations in these veins, suffered different physico-chemical changes namely: $f \mathrm{O}_{2}, \mathrm{FS}$ and $\mathrm{pH}$ changes allowing transportation and the associated deposition of $\mathrm{U}$ and $\mathrm{Au}$ together with sulphides in the study silica veins.

\section{Acknowledgements}

We would like to express our deep thanks to Prof. Zeinab Abed El-Kader and Prof, Mahmoud Hassaan for their supporting and helpful comments which led to an important of the manuscript.

\section{REFERENCES}

Abu Dief, A., 1985. Geology of uranium mineralization in E1-Missikat, Qena-Safaga road, Eastern Desert, Egypt. M. Sc. Thesis. Fac. Sci., Al-Azhar Univ., Cairo. 103 p.

Abu Dief, A., 1992. The relation between the uranium mineralization and tectonics in some Pan-African granite, west of Safaga, Eastern Desert, Egypt. Ph. D. Thesis Fac. Sci., Assiut Univ.,218p.

Abu Dief, A.; Saleh, E. A., and Mohamed, N., 1997. Geological and geochemical studies of black silica at El Missikat pluton, Central Eastern Desert. Egypt. Acad. Sci.,. 47, 335-346.

Ahmed, N. A.,1991. Comparative study of the accessory heavy minerals in some radioactive rocks of Gabal El-Missikat and Gabal El-Erediya, Eastern Desert, Egypt and their alluvial deposits. M.Sc. Thesis, Fac. Sci., Cairo Univ., Egypt, 244 p.

Ammar, F. A.; Hassaan, M. M.; El-Rahmany, M., and Dourgham, E., 2005. Ore Mineralogy of Gold and Associated Sulphide Minerals in Some Deposits in the Central -Southern Eastern Desert, Egypt. Al-Azhar Bull. Sci. , 17, No.2 (Dec.), 47-75.

Ammar, F. A., 2007. Mineralogical and Geochemi- cal Studies For The Sulphide Minerals Association In Gabal El-Missikat Uranium Mineralization, Central Eastern Desert, Egypt. Egyp., J. Miner., In Press.

Amer, T.E.; Ibrahim, T.M., and Omar, S.A., 2005. Microprobe studies and some rare metals recovery from El-Missikat mineralized shear zone, Eastern Desert, Egypt. $4^{\text {th }}$ Inter. Confer. Geol. Africa, Fac. Sci., Assiut Univ., Egypt, 2, 225238.

Attawyia, M. Y.,1984. On the geochemistry and gnesis of uranium mineralization of El-Missikat area, Egypt. Ann. Geol. Surv. Egypt, 13, $1-13$.

Bakhit, F. S., 1978. Geology and radioactive mineralization of G. El Missikat area, Eastern Desert: Ph. D. Thesis, Ain Shams Univ., Cairo, $289 \mathrm{p}$.

Bakhit, F.S., Assaf, H.A. and Abu-Deif, A.A., 1985 .Correlation study on the geology and radioactivity of surface and subsurface working in ElMissikat area, Central Eastern Desert, Egypt. Mining. Geol., 35, 345-354.

Dubessy, J.; Ramboz, C.; Nguyen Trung, C.; Cathelineau, M.; Charoy, B.; Cuney, M.; Leroy, J.; Poty, B., and Weisbrod, A., 1987. Physical and chemical controls $\left(\mathrm{fO}_{2}, \mathrm{~T}, \mathrm{pH}\right)$ of the opposite behaviour of $U$ and $\mathrm{Sn}-\mathrm{W}$ as exemplified by hydrothermal deposits in France and Great Britain, and solubility data. Bull. Mineral., 110., 261-281.

El-Kassas, I. A., 1974 : Radioactivity and geology of Wadi Atalla area Eastern Desert of Egypt: $\mathrm{Ph}$. D. Thesis, Faculty of science, Ain Shams University, Cairo, 502P.

El Shazly, E. M.; Dixon, T. H.; Engel, A. E. J; Abdel-Meguid, A., and Stern, R. J.,1981. LatePrecambrian crustal evolution of Afro-Arabian from oceanic arc to craton. Egypt. J. Geol., 4, No. 1-2, 101-121.

El-Sherif, A.,2013. Mineralogical characterization of the alteration facies at Gabal El-Missikat area, Central Eastern Desert, Egypt. Nuclear 
Sciences Scientific Journal, 2,1-21.

El-Tahir, M. A., 1985. Radioactivity and mineralization of granitic rocks of El-Missikat occurrence.and comparison to El-Missikat-Rei ElGarra occurrence, Eastern Desert, Egypt. Ph. D. Thesis, Al Azhar Univ. Cairo, 133P.

Habib, M. E.,1982. Landsat investigation of mineralizad granites in the area between Gabals El-Urf and El-Erediya due best of Safaga, Egypt $8^{\text {th }}$ Int. Data, LARS/ Purdue Univ., West Lafayette, U. S. A., 441-446.

Hassaan, M.M., 2011. Metallic Ore Deposits in The Nubian Shield in Egypt: Tectonic Environs, Geochemical Behaviour, Promising Sites. LAMBERT, Acad. Publ., London, UK, $256 \mathrm{p}$.

Hussein, H. A.; Hassan, M. A.; El-Tahir, M. A., and Abu Dief, A.,1986. Uranium bearing siliceous veins in younger granites, Eastern Desert. Egypt: Inter. Atomic Agency report, No. 361, 143-157.

Ibrahim, T. M., 2002. Geologic and radioactive studies of the basement-sedimentary contact in the area West Gabal El Missikat, Eastern Desert. Egypt. Ph. D Thesis. Fac. Sci., Mansoura Univ., 215p.

Mohamed, N. A., 1988. Mineralogical and petrographical characteristics of some alteration products related to U-Mineralization in El-Missikat-El-Erediya area. Eastern Desert, Egypt. Ms. C. Thesis, Cairo Univ. ,118p.

Mohamed, N. A.,1995. Distribution and extraction of uranium and some trace elements from mineralized zone of El Missikat-El Erediya area. E.D. Egypt, Ph. D. Thesis, Cairo Univ., 184p.

Orabi, F. ,1999. Geologic, petrographic and geochemical studies of uraniferous granitoids in El Garra-El Gigami area, central Eastern Desert, Egypt. South Valley Univ., 151p.

Vanhanen, E. ,1987. The uraniferous mineralization in the Kusamo schist belt, Northwestern Finland. Proceeding of the "International workshop on metallogenesis of Uranium deposits”, IAEA Vienna, March 1987, (in press).

\section{الإنتماء الوراثي لتمعدنات الذهب واليورانيوم في جرانيت المسيكات، وسط الصحراء الشرقية، مصر في جر}

$$
\text { فتحي إبر اهيم عمار، سيد أحمد محمد عمر و السيد حسن الصاوي }
$$

يتأثر جر انيت جبل المسيكات و الذي يعتبر واحداً من أهم تواجدات اليور انيوم في الصحر اء الثرقية

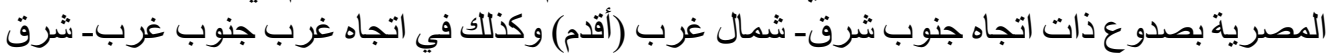

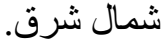

تتأثر الحواف الثمالية الغربية لجر انيت المسيكات بمتاخمتها لصخور الكوارتزدايوريت النيسوزي بنطاقات قص ذات اتجاه من غرب جنوب غربـ شرق شمال شرق الي جنوب غربـ شمال شرق وذات

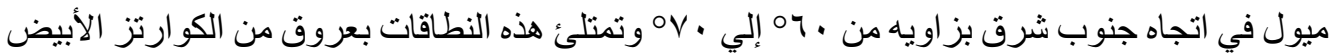

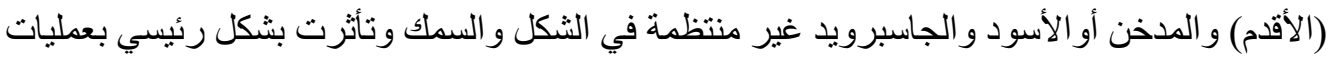

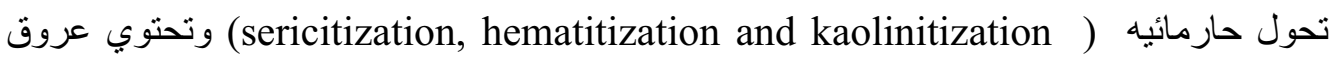
الكوارتز المدخن والأسود علي تمعدنات يور انيوم ثانويه وفلوريت وكبريتدات وكذللك الذهب. أثنتت در اسات الأسطح المصقو له لصخور الدر اسة و التحليل بو اسطة الميكروسكوب الإلكتروني 
الماسح والإمتصاص الذري والبلازما وجود معادن الجالينا والبيريت و الكالكوبيريت والسفاليريت

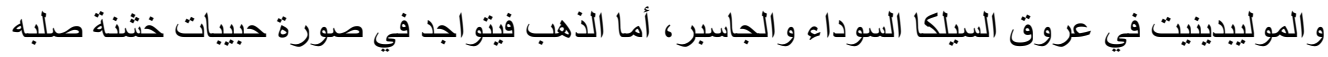
ذات اللون الأصفر والبرونزي المميز مصاحب لتجمعات معادن البيريت، الكالكوبيريت، السفاليريت،

$$
\text { الثييليت و أكاسيد الحديد. }
$$

من البيانات التجريبيه يتحرك اليور انيوم بسهوله في الوسط المؤكسد في صورة ايون سداسي

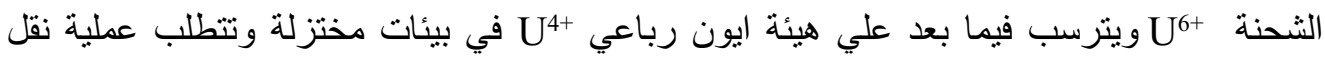

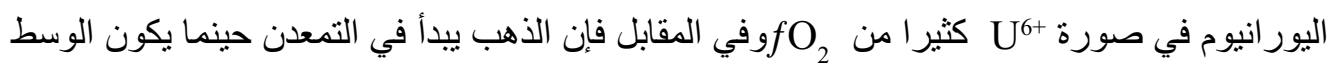
حامل لأيون كلوريد الذهب (-AuCl ${ }^{3-}$ ( يتأثر جبل المسيكات بمحاليل أيونات كلوريد الذهب الحارمائيه

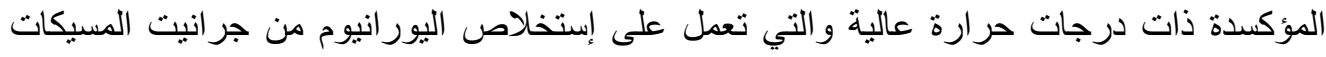

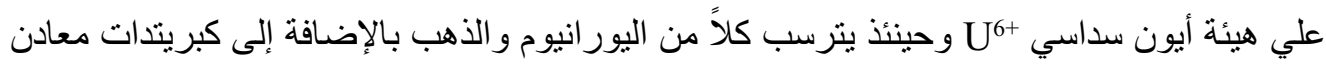
الرصاص، الزنك، الحديد و الموليبدنوم مع زيادة ايونات الكبريت S+2 في المحاليل الحارمائية ذات 